\title{
UNEMPLOYED PEOPLE AGED 50 AND OLDER IN THE STATISTICS OF EMPLOYMENT OFFICES OF THE PODKARPACKIE PROVINCE
}

\begin{abstract}
In this article has been discussed the matter of unemployment among people who are more than 50 years old and are registered in the Podkarpackie Province. The categories of the unemployed belonging to the mentioned age group have undergone a detailed survey and they have been compared to thestructure of the unemployed population in the Podkarpackie Province. The changes the categories of the unemployed 50+ were affected by in the period of 2010-2015 have also been included. The analyses have been supported by the data available from official statistical reporting, especially obtained from the resources of the Central Statistical Office (GUS), including the Local Data Bank and the Economic Activity Survey (BAEL). In the analytic process basic statistical methods have been used and the results have been presented in tables. The time range of analyses is 2010-2015. The Podkarpackie Province is an example of the labour market which is characterised by,in relation to the Polish standards, a high unemployment rate and unfavourable structure of unemployment duration.One fifth of the unemployed registered here arepeople in their 50s and older. The analyses present this category of the unemployed as a community relatively poorly educated and remaining unemployed for a long time, and constantly growing. The data presented in this article will be a basis for a research project planned for 2016, to be carried out on a sample of the unemployed 50+ of the Podkarpackie Province. The analysis may also be useful while developing detailed programmes and projects aimed at professionalactivation of people in their $50 \mathrm{~s}$ and older by state and private labour market subjects.
\end{abstract}

Keywords: unemployed 50+, unemployment, employment, professional activity.

\section{INTRODUCTION}

Due to the changes that have occurred in the Polish labour market in the recent years, which are a consequence of demographic factors (increased migrations, population ageing and elongation of life expectancy with health improvement of the older generation at the same time), the matter of using the potential that people of the generation 50+ have is more and more pressing problem for employment policy. Meanwhile, people who belong to this age category struggle with considerable difficulties infinding or maintaining a job. This fact is reflected in unfavourable indicators characterising the situation of this age category on the labour market. Stereotypes about people belonging to the category 50+ make them perceived as less energetic than they used to be, and little mobile.There are still lots of employers who do not see the advantages of employing people who are 50 and older. Meanwhile, specialists and politicians have no doubts that the group 50+ constitute

\footnotetext{
${ }^{1}$ Paweł Walawender,PhD, Department of Social Research Methodology, The Pedagogical University of Cracow, e-mail: pwalawender@poczta.onet.pl
} 
great and valuable potential on the labour market. ${ }^{2}$ The Lisbon Strategy, developed by the European Union, assumes, among others, an increase in the employment rate in the group of people aged between 50 and 64 to $50 \%$ (it is now 27\% in Poland). In Poland,people older than 50 are one of the groups recognised as being in a special situation on the labour market, hence, they are entitled to particular help, so the importance of this problem has been reflected in the Act on Employment Promotion and Labour Market Institutions.

The aim of this article is to present and analyse the situation of the unemployed aged 50+ on the labour market of the Podkarpackie Province: the region which is still distant from the majority of regions in Poland in respect of both the economy and thesituation on the labour market. ${ }^{3}$

This article presents selected issues relating to the statistics for demographics and the labour market with particular reference to people aged 50 and older. The research has been based onthe data available from official statistical reporting, mainly obtained from the resources of the Central Statistical Office, including the Local Data Bank and the Economic Activity Survey (BAEL). The time range of analyses is 2010-2015.

\section{THE PEOPLE OF GENERATION 50+ ON THE POLISH LABOUR MARKET IN THE LIGHT OF BAEL}

The economic activity in Poland is described on the basis of the results of the survey called in short BAEL, from Badanie Aktywności Ekonomicznej (Economic Activity Survey), which has been carried out with the use ofthe representational method by the Central Statistical Office since 1992. The main methodological assumption of BAEL is using a job as the criterion for dividing people into three categories: professionally passive, unemployed and working.

The level of professional activity in the Polish society is still too low, which is a disturbing phenomenon, especially in the face of population ageing. The indicators portrayingprofessional activity, employment and unemployment are strongly correlated with age. In Poland, the economic activity rate of people aged 50 and older in 2014 (average annual data) was $34.3 \%$. At the time, the average for the whole working-age (1859/64 years) population in Poland was $74.3 \%$. In the Podkarpackie Province this rate was $33.3 \%$ for people aged 50 and older and $72.5 \%$ for the whole working-age population in the province. The research shows that health condition, age and personal preferences (willingness to retire) are the main factors that affect professional activity, leading to its cessation. Another group of determinantswhich makes a contribution towards increasing the probability of becoming unemployed again is the factors closely related to working conditions, such as forms of employment and working hours or the subjective feeling of

\footnotetext{
${ }^{2}$ N.G Pikuła, Niewykorzystany potencjał zawodowy osób 50+ na rynku pracy, Horyzonty Wychowania 14 (30), pp.194-200.

${ }^{3} \mathrm{cf}$. A. Barwińska-Małajowicz, K. Puchalska, Odrabianie dystansu rozwojowego w województwie podkarpackim w kontekście bezpośrednich inwestycji zagranicznych i rynku pracy, [in:]Nierówności Spoteczne a Wzrost Gospodarczy, issue no. 37 (1/2014) pp.421-433.

${ }^{4}$ Ministry of Labour and Social Policy, Osoby powyżej 50 roku życia na rynku pracy w 2014 roku, http://www.mpips.gov.pl/analizy-i-raporty/raporty-sprawozdania/rynekpracy/sobypowyej50rokuycianarynkupracy/osoby-powyzej-50-roku-zycia-na-rynku-pracy-w-2013roku/, p. 2 (access: 11.04.2016).
} 
job satisfaction. The system conditions, e.g. pension entitlement, also have a great impact. ${ }^{5}$ The relatively low level of professional activity of people aged 50 and older is connected with social stereotypes about elderly employees (e.g. people before retirement take the place of the young who just enter the labour market). ${ }^{6}$ The low level of professional activity of the elderly also results from the active policy of the country which has encouraged them to retire earlier and receive disability pensions. It is worth noticing the economic instrument affecting the situation in the labour market which is the minimum wage. Its rate in relation to the amount of the social security benefits makes working in Poland relatively unattractive. ${ }^{8}$

In 2014 the employment rate of people aged 50 and older in Poland was $32.1 \%$ (average annual data). At the time, the average for the whole working-age (18-59/64 years) population in Poland was 67.5\%. In the Podkarpackie Province this rate was $30.7 \%$ for people aged 50 and older and $62.1 \%$ for the whole working-age population in the province.

The unemployment rate of working-age people (18-59/64 years) in Poland was calculated by BAEL in 2014 and was $9.0 \%$. In the Podkarpackie Province this rate was $14.0 \%$. The unemployment rate of people aged between 50 and 64 was lower in Poland than the average in the EU and was 6.9 against $7.4 \%$ in the EU. The unemployment rates of elderly people higher than in Poland were reported in 12 countries of the EU, i.e.: Spain $(20.3 \%)$, Greece $(18.5 \%)$, Cyprus $(15.3 \%)$, Portugal $(12.7 \%)$, Croatia (12.0\%), Slovakia $(11.1 \%)$, Bulgaria (10.8\%), Lithuania (9.9\%), Latvia (9.8\%), Ireland (9.2\%), Slovenia $(7.8 \%)$ and Finland $(7.0 \%){ }^{9}$

\section{THE PROBLEM OF UNEMPLOYMENT IN THE PODKARPACKIE PROVINCE}

Unemployment is an inherent element of each market economy indeed, however, there are limits that should not be exceeded. Some authors define this limit as $2-3 \%$ and others as up to $5 \%$ of jobless people among all professionally active. Unfortunately, the unemployment level in the Podkarpackie Province exceeds this limit several times. At the end of December 2015 the unemployment rate was 13.2\%, which was relatively high in comparison with the national average $(9.8 \%)$.

At the same time, 123514 unemployed were registered in the province. Women were slightly in majority (51.5\%). At the end of 2015, unemployment rates that were higher than in the Podkarpackie Province, were reported in three provinces: Warmińsko-Mazurskie $(16.3 \%)$, Zachodnio-Pomorskie and Kujawsko-Pomorskie (13.3\%).At that time, the

\footnotetext{
${ }^{5}$ A. Abramowska-Komon et al., Portret generacji 50+ w Polsce i w Europie. Wyniki badania zdrowia, starzenia się i przechodzenia na emeryturę w Europie (SHARE), http://zdrowiepol.nazwa.pl/share/files/publikacje/ibe-raport-krajowy-SHARE.pdf, p.29 (access: 30.03.2016)

${ }^{6}$ N.G Pikuła, op. cit., pp. 196-198

${ }^{7}$ B. Jośko, Aktywność zawodowa osób starszych, [in:] red. Noga M., Stawicka M.K. Rynek pracy $w$ Polsce $w$ dobie integracji europejskiej i globalizacji, Warszawa, CeDeWUu Sp. z o.o., Warszawa 2011, p.87.

${ }^{8}$ G. Wałęga, Aktywność Ekonomiczna osób starszych, [in:]Rynek pracy w Polsce. Aspekty ekonomiczno-społeczne, ed. by. Z. Dach, Wydawnictwo Uniwersytetu Ekonomicznego w Krakowie, Kraków 2008, pp. 111-112.

${ }^{9}$ Ministry of Labour and Social Policy, op. cit., p. 5
} 
lowest unemployment rate was reported in the provinces: Wielkopolskie $(6.2 \%)$, Śląskie (8.2\%) and Mazowieckie (9.7\%).

Apart from the high unemployment level in the Podkarpackie Province, its widespread range on the district level is the problem. A range between the highest and the lowest employment rate in the province in December 2015 was 14.9 points. The highest unemployment rate was reported in the following districts: Lesko(20.8\%), Brzozów(20.7\%) and Strzyżów (20.2\%). A group of the districts with the lowest unemployment rate in 2015 consisted of: Krosno (5.9\%), Rzeszów (7.3\%) and Stalowa Wola (9.7\%).

During the period under analysis, in the Podkarpackie Province there were registered 14417 unemployed entitled to unemployment benefits, which was $11.7 \%$ of the total population in the survey.

An immensely important matter relating to the possibility of reducing unemployment is not only the number of the unemployed, but also the categories they are classified into: gender, age, educational level, work experience and the duration of unemployment.

The age of the unemployed is a characteristic which significantly affects the chances of finding a job. According to the data at the end of December 2015, people aged between 25 and 34 were the largest age group among the registered unemployed in the Podkarpackie Province (30.2\%). The second largest group was people aged between 35 and $44(21.2 \%)$. The unemployed aged $45-54$ were $18.0 \%$ during this period, those aged 55 and older $-12.9 \%$ and those who were 24 and less $-17.7 \%$.

Another important criterion for dividing the unemployed is education. At the end of 2015, there were the fewest unemployed, i.e. $10.4 \%$, among secondary-school graduates. Slightly more were university graduates $(14.2 \%)$. One in fouramong the unemployed graduated from a post-secondary or vocational secondary school (25.5\%) and one in five middle school $(20.1 \%)$. The percentage of people who graduated from a basic vocational school was $29.7 \%$.

Work experience significantly affects the chances of the unemployed on the labour market. People who have never worked usually experience the greatest difficulties in finding a job. At the end of December 2015, among all the unemployed registered in the Podkarpackie Province there were $19.8 \%$ of such people. People who had work experience between 1 and 5 years were $22.2 \%$. Next, $18.7 \%$ of unemployed had work experience not longer than 1 year. The fewest unemployed were in the category of people who had work experience longer than 30 years (3.0\%).

Being unemployed for a long time reduces the chances of finding a job, which, in turn, contributes to a decrease in the social status of the unemployed and their families and makes their financial situation worse.Therefore, the time-of-being-unemployed criterion is significant for estimating the unemployment structure. According to the data on 31 December 2015 people remaining unemployed for longer than 12 months were $44.4 \%$ of all the unemployed (where $28.9 \%$ were unemployed longer than 24 months). The smallest group was the people remaining unemployed for not longer than one month (8.6\%).

\section{THE UNEMPLOYED AGED 50 AND OLDER IN THE STATISTICS OF EMPLOYMENT OFFICES OF THE PODKARPACKIE PROVINCE}

Pursuant to the Act of 20 April 2004 on Employment Promotion and Labour Market Institutions, an unemployed person over 50 means a person that is at least 50 yearsold in the calendar year when the labour market services and instruments apply to them. 
According to the data at the end of 2015 in the Podkarpackie Province there were registered 27449 unemployed aged 50 and over.It was $22.2 \%$ of all the unemployed registered in the province. Women were $39.3 \%$ of the analysed category. In comparison, the percentage of unemployed aged 50 and over in Poland then was 27.5\%, and the percentage of women in this discussed category of the unemployed was $52.2 \%$.

The mentioned percentage of the unemployed aged 50 and over among all the registered unemployed in Podkarpackie was the lowest in Poland. It is worth noticing that this percentage increased in relation to 2010 by 6.1 , while in Poland this percentage increased by 5.6. In 2015 the highest percentage of unemployed aged 50 and over was reported in the provinces: Dolnośląskie(33.3\%), Opolskie (31.6\%) and Zachodniopomorskie $(31.4 \%)$. Next, the lowest percentage was reported in the already mentioned Podkarpackie(22.2\%), Lubelskie (22.3\%) and Świętokrzyskie (24.6\%).

\subsection{Education}

It is a common opinion that the higher education, the lower the risk of losing a job and the better chances of receiving more attractive wages. Of course, one must remember that it is not guaranteed by every education and that skills must be constantly improved. ${ }^{10}$

Table1. The structure of education of the unemployed aged 50 and older in the Podkarpackie Province according to the data at the end of 2010 and 2015

\begin{tabular}{|l|c|c|c|c|}
\hline \multirow{2}{*}{} & \multicolumn{2}{|c|}{2010} & \multicolumn{2}{c|}{2015} \\
\cline { 2 - 5 } & $\begin{array}{c}\text { Number of } \\
\text { unemployed }\end{array}$ & Per cent & $\begin{array}{c}\text { Number of } \\
\text { unemployed }\end{array}$ & Per cent \\
\hline University & 626 & 2.7 & 970 & 3.5 \\
\hline $\begin{array}{l}\text { Post-secondary and vocational } \\
\text { secondary school }\end{array}$ & 4072 & 17.8 & 5286 & 19.3 \\
\hline General secondary school & 1072 & 4.7 & 1236 & 4.5 \\
\hline Basic vocational school & 7752 & 33.9 & 10821 & 39.4 \\
\hline Middle school and lower & 9333 & 40.8 & 9136 & 33.3 \\
\hline
\end{tabular}

Source: Own study based on the data of GUS

Among the citizens of Podkarpackie belonging to the category of the unemployed aged 50 and over, according to the data at the end of 2015, the largest group were basic vocational school graduates $(39.4 \%)$ and middle school graduates, together with those with lower education (33.3\%).The lowest percentage of unemployed aged 50 and over was university graduates - only $3.5 \%$ of all the unemployed belonging to the discussed category of the unemployed registered in employment offices of the Podkarpackie Province. In comparison with 2010 , it is distinctlyvisible that the unemployment rate of middle school graduates and those with lower education is lower (by 7.5 per cent) and that of basic vocational school graduates is higher (5.5 per cent).

\footnotetext{
${ }^{10}$ cf. T. Budnikowski, Bezrobocie na świecie $i$ w Polsce, Instytut Zachodni, Poznań 2002, p. 24.
} 
Table2. Comparison between the structure of education of all the unemployed registered in the Podkarpackie Province and unemployed aged 50 and older according to the data at the end of 2015.

\begin{tabular}{|l|c|c|c|c|}
\hline \multirow{2}{*}{} & \multicolumn{2}{|c|}{ Province in total } & \multicolumn{2}{c|}{$\begin{array}{c}\text { Unemployed aged 50 and } \\
\text { older }\end{array}$} \\
\cline { 2 - 5 } & $\begin{array}{c}\text { Number of } \\
\text { unemployed }\end{array}$ & Per cent & $\begin{array}{c}\text { Number of } \\
\text { unemployed }\end{array}$ & Per cent \\
\hline University & 17588 & 14.2 & 970 & 3.5 \\
\hline $\begin{array}{l}\text { Post-secondary and vocational } \\
\text { secondary school }\end{array}$ & 31542 & 25.5 & 5286 & 19.3 \\
\hline Secondary school & 12875 & 10.4 & 1236 & 4.5 \\
\hline Basic vocational school & 36625 & 29.7 & 10821 & 39.4 \\
\hline Middle school and lower & 24884 & 20.1 & 9136 & 33.3 \\
\hline
\end{tabular}

Source: Own study based on data of GUS

The categories of the unemployed aged 50 and over in the province were disadvantageous to the indicators of the categories calculated for the whole unemployed population in the Podkarpakie Province. It is noticeable that the percentage of university graduates aged 50 and over is much lower (by 10.7 per cent) and that of middle school graduates and those with lower education is higher (by 13.2 per cent). The unemployed aged 50 and over are less educated in relation to the whole unemployed population registered in the province. Some differences in the categories are also present regarding gender.

In general, the women of the discussed category are better educated than men, however, it must be remarked that the differences are not so much noticeable in comparison to the whole unemployed population. Women were in majority regarding two levels of education: post-secondary, vocational secondary and secondary.

\subsection{Work experience}

In the Podkarpackie Province the largest group of unemployed aged 50 and over had work experience between 20 and 30 years $(29.7 \%)$ and between 10 to 20 years $(27.9 \%)$.

Table3. The structure of work experience of the unemployed aged 50 and older in the Podkarpackie Province according to the data at the end of 2010 and 2015.

\begin{tabular}{|l|c|c|c|c|}
\hline \multirow{2}{*}{} & \multicolumn{2}{|c|}{2010} & \multicolumn{2}{c|}{2015} \\
\cline { 2 - 5 } & $\begin{array}{c}\text { Number of } \\
\text { unemployed }\end{array}$ & Per cent & Number of unemployed & Percent \\
\hline Up to 1 year & 1919 & 8.4 & 2001 & 7.3 \\
\hline $1-5$ & 1487 & 6.5 & 1769 & 6.4 \\
\hline $5-10$ & 1945 & 8.5 & 2875 & 10.5 \\
\hline $10-20$ & 5801 & 25.4 & 7671 & 27.9 \\
\hline $20-30$ & 7286 & 31.9 & 8160 & 29.7 \\
\hline 30 and more & 2820 & 12.3 & 3630 & 13.2 \\
\hline No work experience & 1597 & 7.0 & 1343 & 4.9 \\
\hline
\end{tabular}

Source: Own study based on data of GUS

The fewest unemployed were among those having no work experience $(4.9 \%)$ and experience between 1 to 5 years $(6.4 \%)$. 
In comparison to 2010 no radical changes in the structures took place. The greatest changes were increasing the percentage of people having work experience between 10 and 20 years (by 2.6) and decreasing the percentage of people having work experience between 20 and 30 years (by 2.2) and those having no work experience (by 2.1).

Table4. Comparison between the structure of work experience of all the unemployed registered in the Podkarpackie Province and the unemployed aged 50 and older according to the data at the end of 2015 .

\begin{tabular}{|l|c|c|c|c|}
\hline \multirow{2}{*}{} & \multicolumn{2}{|c|}{ Province in total } & \multicolumn{2}{c|}{ Unemployed aged 50 and older } \\
\cline { 2 - 5 } & $\begin{array}{c}\text { Number of } \\
\text { unemployed }\end{array}$ & Per cent & $\begin{array}{c}\text { Number of } \\
\text { unemployed }\end{array}$ & Per cent \\
\hline Up to 1 year & 23095 & 18.7 & 2001 & 7.3 \\
\hline $1-5$ & 27463 & 22.2 & 1769 & 6.4 \\
\hline $5-10$ & 17023 & 13.8 & 2875 & 10.5 \\
\hline $10-20$ & 17334 & 14.0 & 7671 & 27.9 \\
\hline $20-30$ & 10465 & 8.5 & 8160 & 29.7 \\
\hline 30 and more & 3723 & 3.0 & 3630 & 13.2 \\
\hline No work experience & 24411 & 19.8 & 1343 & 4.9 \\
\hline
\end{tabular}

Source: Own study based on data of GUS

The categories of the unemployed aged 50 and over were disadvantageous to the indicators of the categories calculated for the whole unemployed population in the Podkarpackie Province. It is noticeable, which is natural, that the percentage of people having the longest work experience, i.e. 20-30 years (by 21.2 per cent) and 30 years and more (by 10.2 per cent) is much higher and of people having short work experience, i.e. up to 1 year (by 15.8 per cent) and no experience (by 14.9 per cent) is lower. Some differences in these categories are also present regarding gender.

In general, it is noticeable that the percentage of women having work experience between 10 and 20 years (as far as by 10 per cent) is higher and of women having the longest work experience (by 7.6 per cent) is lower. These differences are also significant in relation to the unemployment structure in the province, where the differences between the categories of men and women are smaller.

\subsection{The period of unemployment}

Table 5. The periods of unemployment among the people aged over 50 in the Podkarpackie Province as of the end of 2010 and 2015.

\begin{tabular}{|c|c|c|c|c|}
\hline \multirow{2}{*}{$\begin{array}{c}\text { Period of } \\
\text { unemployment }\end{array}$} & \multicolumn{2}{|c|}{2010} & \multicolumn{2}{|c|}{2015} \\
\hline & $\begin{array}{l}\text { Number of } \\
\text { unemployed }\end{array}$ & Per cent & $\begin{array}{l}\text { Number of } \\
\text { unemployed }\end{array}$ & Per cent \\
\hline Do 1 & 1575 & 6.9 & 1514 & 5.5 \\
\hline $1-3$ & 3325 & 14.5 & 3251 & 11.8 \\
\hline $3-6$ & 2348 & 10.3 & 2846 & 10.4 \\
\hline $6-12$ & 3652 & 16.0 & 3792 & 13.8 \\
\hline $12-24$ & 4380 & 19.2 & 4629 & 16.9 \\
\hline Over 24 & 7575 & 33.1 & 11417 & 41.6 \\
\hline
\end{tabular}

Source: Own study based on data of GUS 
As of the end of 2015 among the unemployed aged over 50, registered on the territory of Podkarpacie, the largest group was that of people who keep being unemployed for over two years. Those people made $41.6 \%$ of the total unemployed in the category under analysis. A large group of the unemployed people aged over 50 was made of people who have been in the register of the unemployed for a year up to two years $(16.9 \%)$. The lowest percentage of the unemployed was noted among the people who have been unemployed for up to one month $(5.5 \%)$. In comparison to the year 2010, the percentage of people who have remained in the register of the unemployed for over two years has increased (by 8.5 per cent).

Table 6. Comparison between the periods of unemployment between the unemployed in general, registered in the Podkarpackie Province, and the unemployed over the age of 50 as of the end of 2015.

\begin{tabular}{|l|c|c|c|c|}
\hline \multirow{2}{*}{} & \multicolumn{2}{|c|}{ Province total } & \multicolumn{2}{c|}{ The unemployed aged over 50 } \\
\cline { 2 - 5 } & $\begin{array}{c}\text { Number of } \\
\text { unemployed }\end{array}$ & Per cent & $\begin{array}{c}\text { Number of } \\
\text { unemployed }\end{array}$ & Per cent \\
\hline Up to 1 & 10677 & 8.6 & 1514 & 5.5 \\
\hline $1-3$ & 22088 & 17.9 & 3251 & 11.8 \\
\hline $3-6$ & 18058 & 14.6 & 2846 & 10.4 \\
\hline $6-12$ & 17935 & 14.5 & 3792 & 13.8 \\
\hline $12-24$ & 19090 & 15.5 & 4629 & 16.9 \\
\hline Over 24 & 35666 & 28.9 & 11417 & 41.6 \\
\hline
\end{tabular}

Source: Own study based on data of GUS

The structure of the unemployed aged over 50 differed significantly from the structure of the total number of the unemployed in the Podkarpackie Province. It may be easily noticed that there is a considerably greater number of people who remain in the register of the unemployed for a period longer than two years (by 12.7 per cent) and a lower number of people in the category of the unemployed who remain in the register for a shorter period of time (from 1 month by 3.1 per cent; from 1 to 3 months by 6.1; from 6 to 12 months by 4.2). It was also observed that some differences exist between sexes.

Generally, the data that draws attention is the higher proportion of women among the unemployed remaining in the register for longer than 24 months (by 5.3 per cent). There are no significant differences in this respect in comparison to the total province structure.

\section{SUMMARY}

In spite of some improvements in rates describing the situation in the labour market in the Podkarpackie Province, this market is still characterized by higher than average unemployment rates, low level of employment and unfavourable structure of unemployment duration. Many categories of the unemployed are in a difficult situation. However, special attention should be paid to people aged 50+. The participation of this category in comparison toall the ones registered in offices of the Podkarpackie Province is relatively low indeed, but, due to the migration of the young and constant ageing of the population, it will increase systematically. On the other hand, the samefactors may be helpful for people in their 50s in getting a job.More and more job offers appear and 
employers are more open to the $50+$ generation. ${ }^{11}$ Especiallythat, as it results from surveys, people 50+ are responsible, conscientious and reliable employees. Unfortunately, on the other hand, they are often relatively poorly educated and remain unemployed for a long time, which makes them lose the skills they have acquired earlier. Psychological issues are another problem.Many people of the generation 50+do not believe in their own strength and abilities, they have low self-esteem, are unwilling to make changes and assume in advance that these changes do not apply to them. They just become professionally passive. ${ }^{12}$ What is more, the negative stereotypical perception of this age group, which is still present among the employers, does not help.

Considering the importance of the problem, improving the situation of the people belonging to the category 50+ on the market of Podkarpackie should be one of the most significant challenges for the local labour market subjects. Regarding the fact that Poland varies in the level of socio-economic development andsome structural problems exist, even one commonly accepted idea of solving problems of the people aged 50+ has not been developed so far. One of the reasons of this state of affairs is the differentiation of the socio-economic development levels regarding regions. Therefore, developing specific actions, programmes and projects requires taking the regional specifics into account. ${ }^{13}$ Therefore, further analytical and research works are needed in order to act more effectively. This article is a contribution to such analytical operations.

\section{BIBLIOGRAPHY}

[1] Abramowska-Komon A. at al. 2014. Portret generacji 50+ $w$ Polsce $i w$ Europie. Wyniki badania zdrowia, starzenia się i przechodzenia na emeryture w Europie (SHARE), http://zdrowiepol.nazwa.pl/share/files/publikacje/iberaport-krajowy-SHARE.pdf, (access: 30.03.2016)

[2] Analiza sytuacji osób bezrobotnych w wieku 50+ na podstawie danych statystycznych $w$ ramach projektu PI Indywidualny koszyk świadczeń osób 50+. Model trójsektorowej wspótpracy w zakresie rynku pracy, Lublin 2012, http://puplublin.pl/asynch/download/f_id/716. (access: 30.03.2016).

[3] Barwińska-Małajowicz A., Puchalska K., Odrabianie dystansu rozwojowego w województwie podkarpackim $w$ kontekście bezpośrednich inwestycji zagranicznych i rynku pracy, Nierówności Społeczne a Wzrost Gospodarczy, $37(1 / 2014)$.

[4] Budnikowski T., Bezrobocie na świecie $i$ w Polsce, Instytut Zachodni. Poznań 2002.

[5] Jośko B., Aktywność zawodowa osób starszych. In: Noga M. (ed.), Stawicka M.K. Rynek pracy w Polsce w dobie integracji europejskiej i globalizacji, Warszawa 2011, CeDeWUu Sp. z o.o.

\footnotetext{
${ }^{11}$ Mól Dariusz, Osoby 50+ na rynku pracy, Bulletin FISE no. 7 May 2008, http://wiadomosci.ngo.pl/files/1bezrobocie.org.pl/public/biuletyny_fise/biuletyn_fise_nr7_osoby_50 _na_rynku_pracy.pdf , p. 5 (access: 30.03.2016).

${ }^{12}$ Ibidem, p. 5.

${ }^{13}$ Analiza sytuacji osób bezrobotnych $w$ wieku $50+$ na podstawie danych statystycznych w ramach projektu PI Indywidualny koszyk świadczeń osób 50+. Model trójsektorowej wspótpracy w zakresie rynku pracy, Lublin 2012, http://puplublin.pl/asynch/download/f_id/716. p.85 (access: 30.03.2016).
} 
[6] Ministry of Labour and Social Policy. Osoby powyżej 50 roku życia na rynku pracy w 2014 roku http://www.mpips.gov.pl/analizy-i-raporty/raportysprawozdania/rynek-pracy/sobypowyej50rokuycianarynkupracy/osobypowyzej-50-roku-zycia-na-rynku-pracy-w-2013-roku/ (access: 11.04.2016).

[7] Mól D., Osoby 50+ na rynku pracy, Bulleting FISE no.7 May 2008, http://wiadomosci.ngo.pl/files/1 bezrobocie.org.pl/public/biuletyny_fise/biulet yn_fise_nr7_osoby_50_na_rynku_pracy.pdf (dostęp: 30.03.2016).

[8] Pikuła Norbert G., Niewykorzystany potencjał zawodowy osób 50+ na rynku pracy, Horyzonty Wychowania 200814 (30).

[9] Wałęga G., Aktywność Ekonomiczna osób starszych. In: Rynek pracy w Polsce. Aspekty ekonomiczno-społeczne. In: Dach Z (ed.). Wydawnictwo Uniwersytetu Ekonomicznego w Krakowie 2008.

\section{BEZROBOTNE OSOBY POWYŻEJ 50 ROKU ŻYCIA W STATYSTYKACH} URZEDÓW PRACY WOJEWÓDZTWA PODKARPACKIEGO

W artykule omówiono kwestię bezrobocia wśród osób w wieku powyżej 50 roku życia zarejestrowanych na terenie województwa podkarpackiego. Szczegółowemu opisowi poddano strukturę bezrobotnych wspomnianej kategorii wiekowej oraz porównano ją do struktury populacji bezrobotnych w województwie podkarpackim. Uwzględniono również zmiany jakim struktura bezrobotnych 50+ podlegała na przestrzeni lat 2010-2015. Do analiz wykorzystano dane dostępne w oficjalnej sprawozdawczości statystycznej, przede wszystkim zaczerpnięte z zasobów Głównego Urzędu Statystycznego, w tym Banku Danych Lokalnych i Badań Aktywności Ekonomicznej Ludności (BAEL). W procesie analitycznym wykorzystano podstawowe metody statystyczne, m.in. wskaźniki struktury i indeksy dynamiki, a wyniki zaprezentowano za pomocą tabel. Zakres czasowy analiz objął lata 2010-2015. Województwo podkarpackie, to przykład rynku pracy chrakteryzującym się dość jak na standardy polskie wysokim bezrobociem i niekorzystną struktura czasu pozostawania bez pracy. Jedną piątą zrejestrowanych tu bezrobotnych stanowią osoby $\mathrm{w}$ wieku 50 i więcej lat. Analizy ukazują tą kategorię bezrobotnych jako zbiorowość stosunkowo słabo wykształconą i przebywającą długo na bezrobociu, której udział systematycznie wzrasta. Zaprezentowane w artykule dane będą podstawą do zaplanowanych na rok 2016 projektu badawczego realizowanych na próbie bezrobotnych 50+ województwa podkarpackiego. Analiza może być również użyteczna przy opracowywaniu szczegółowych programów i projektów mających na celu aktywizację zawodową osób w wieku 50+ przez publiczne i niepubliczne podmioty rynku pracy.

Słowa kluczowe: bezrobotni 50+, bezrobocie, zatrudnienie, aktywność zawodowa

DOI:10.7862/rz.2016.hss.55

Przesłano do redakcji: luty 2016

Przyjęto do druku: wrzesień 2016 